\title{
DEVELOPMENT OF IN VITRO SOMATIC EMBRYOS FROM MUSA spp. cv EMBUL AND KOLIKUTTU (AAB GROUP)
}

\author{
K. HIRIMBUREGAMA and N. GAMAGE \\ Department of Botany, University of Colombo, P.O. Box 1490, Colombo 03.
}

(Received: 13 March 1996; accepted: 07 February 1997)

\begin{abstract}
The study compares somatic embryo development in two local cultivars of Musa (Embul and Kolikuttu - AAB group). Meristematic cells on basic Murashige and Skoog medium (MS) supplemented with 2,4-D $(0.2 \mathrm{mg} / \mathrm{L})$ and $\mathrm{BAP}(1.25 \mathrm{mg} / \mathrm{L})$ results in direct induction of embryo cells without involvement of callus. A physical separation of embryogenic cells by a 'thick' wall is the first stage in somatic embryo development. The group of cells surrounded by a thick wall is then released as globules. Upon successive transfer to two liquid MS culture media, initially with $\mathrm{ABA}(1.25 \mathrm{mg} / \mathrm{L})$, and secondly without any growth regulators, the globules developed into bipolar somatic embryos. There is no significant difference in somatic embryo formation in the two cultivars tested. The development pattern of the somatic embryos appears to be the same as in Musa cv Bluggoe (ABB) except for the time of proembryo initiation and formation.
\end{abstract}

Key words: Banana, Musa spp., somatic embryogenesis.

\section{INTRODUCTION}

Somatic embryogenesis is the development of an embryo from somatic haploid or diploid cells without fusion of gametes. Somatic embryos possess both shoot and root meristems and are capable of forming complete plants. It is known that in vitro somatic embryogenesis offers great potential for crop improvement through the use of efficient cloning and genetic engineering techniques. Direct induction of somatic embryos is an important method of propagation and has been developed in many plants including crops such as rice. ${ }^{1-4}$ It is a promising technique for plant multiplication due to high proliferation potential and minimal genetic instability. ${ }^{1,2,5}$ In dicotyledons, formation of zygotic and somatic embryos progress through similar distinct stages such as globular, heart, torpedo and cotyledonary. However in monocotyledons, there are no distinct stages, ${ }^{6,7}$ the initial stages are identified only as meristematic cell clusters. ${ }^{3,4,8-10}$ But prominent stages thereafter appear to show varying degrees of specialization. ${ }^{11-13}$ Somatic embryogenesis has advanced to such an extent that artificial seeds are available, the process has been automated and sorting of embryos of different stages is now possible. ${ }^{14-16}$ The present study was performed on somatic embryogenesis in two local cultivars of Musa spp. cv Embul and Kolikuttu (AAB) both of which have a high demand locally and abroad.

Abbreviations: 2,4 D - 2,4 Dichlorophenoxy Acetic acid, BAP - 6-Benzyl-Aminopurine, ABA - Abscisic Acid, FAA - Formaline: Acetic Acid - Alcohol ( 5:5:90).. 


\section{METHODS AND MATERIALS}

Proliferating shoot cultures of Musa spp. cv Embul and Kolikuttu (AAB group) at subculture 3 were used. The uppermost part of proliferating shoots (Fig. 1a) was used as the explant (size $0.5 \times 0.5 \mathrm{~cm}^{2}$ ). The explant tissues had 6-8 layers of meristematic cells just below the epidermis (Fig. 1b).

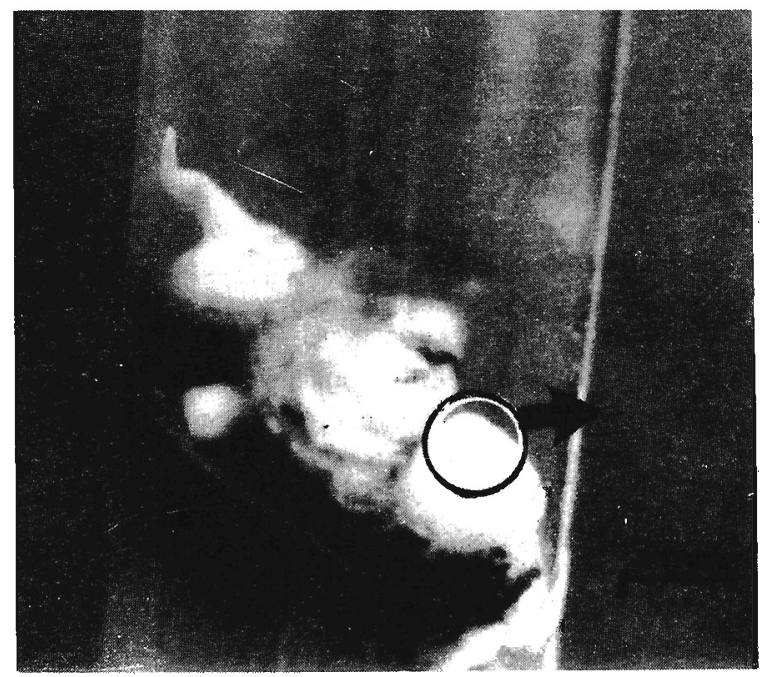

(a)

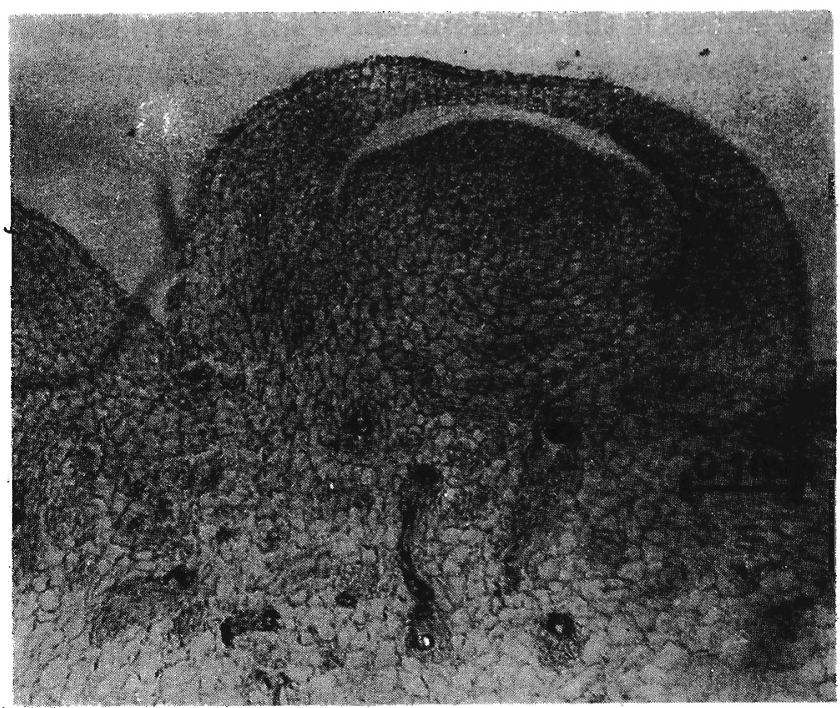

(b)

Figure 1: Explant for somatic embryo development (a) morphology, (b) a longitudinal section. 
Culture medium and culture conditions: Basic Murashige and Skoog (1962) ${ }^{18}$ (MS) in liquid was supplemented with 2,4-D $(0.2 \mathrm{mg} / \mathrm{L})$ and BAP $(1.25 \mathrm{mg} / \mathrm{L})$. An aliquot of $20 \mathrm{~cm}^{3}$ of the medium was dispensed to Erlenmeyer flasks $\left(100 \mathrm{~cm}^{3}\right)$ and were autoclaved at $121^{\circ} \mathrm{C}$ and $120 \mathrm{kPa}$. Thirty such flasks were used for each cultivar and 5 explants per flask were inoculated on the same day. The cultures were incubated under continuous shaking at $60 \mathrm{rpm}$ on an orbital shaker (BR$300 \mathrm{~L})$, at $16 \mathrm{~h}$ light period provided with white fluorescent tubes $\left(4.2 \mathrm{~W} / \mathrm{m}^{2}\right)$. Using a stereo microscope, change in size, morphology and colour (e.g. browning) of the explant were recorded weekly for 15 wks. The number of globular structures of diameter $2 \mathrm{~mm}$ or less, which were released to the medium, was counted every week.

Development of somatic embryos: The globules of size $2 \mathrm{~mm}$ or less, were transferred to MS with ABA (1.25 mg/L) for two weeks and secondly to MS without any growth regulators. Changes in size, shape and colour of the globules were observed every week.

Sample preparation for histological studies: Shoot tip samples were taken randomly just before inoculation (time 0 ) and at 2,4,6 and 8 wks after inoculation. Two samples at each time were fixed in FAA and microtome section cuttings were prepared and were stained with safranin according to Berlyn \& Miksche. ${ }^{19}$ Changes in the meristematic region, formation of globules, procambial strands and xylem elements were studied. Two globules (of diameter $2 \mathrm{~mm}$ ), released by the explant were also fixed for histological observations.

\section{RESULTS AND DISCUSSION}

Both Musa cultivars tested (Embul and Kolikuttu) showed a similar pattern of somatic embryo development but time taken for proembryo formation from explants varied.

\section{Morphological and histological changes in the explant}

One week after inoculation

During the first week after inoculation, the size of the explant increased two fold. Browning of the explant tissue was observed. The number of cell layers and also the width of the meristematic zone were increased, possibly due to active cell division and expansion of the apical meristem.

\section{Two to six weeks exposure to 2,4-D and BAP}

There was a further $25 \%$ increase in size. Shoot structure (meristem with leaf primordia) was still visible at week two (Fig. 2 a). At the beginning of week 4, deeply stained meristematic cell region was still apparent. In addition, groups of meristematic cells which were not previously seen, were present in the 
parenchyma (Fig. 2 b). The shoot structure was not clearly visible at the end of week 4 and thereafter it gradually disappeared.

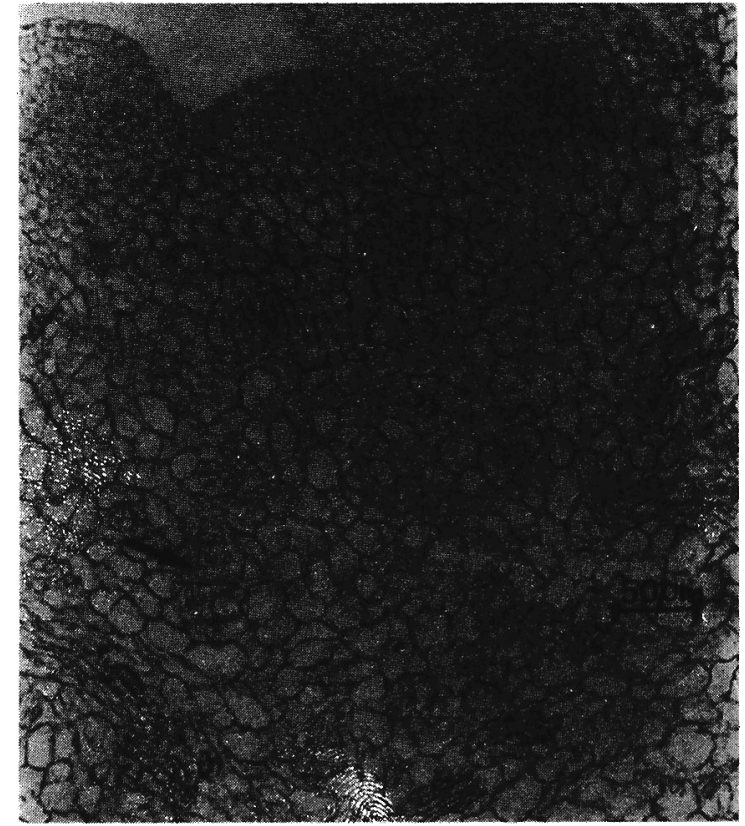

(a)

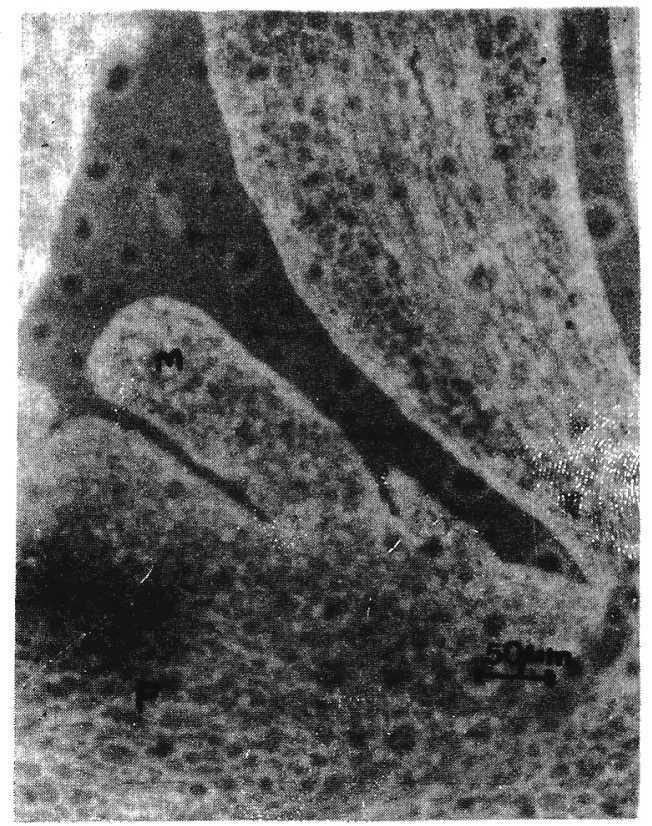

(b)

Figure 2: LS of explant to illustraie changes in the histology with exposure to 2,4-D \& BAP (a) at week two, (b) at week four.

(m: apical meristem, p: parenchyma, the arrow shows a meristematic cell loci) 


\section{Exposure for seven to twelve weeks}

Histological observations at week eight showed groups of cells physically separated by a thick cell wall (Fig. 3). Such physical separation is reported as an initial stage in the development of somatic embryos. ${ }^{3,6}$ The cells in these groups were small in size, had distinct nucleus and nucleolus. They also had dense cytoplasm and a few vacuoles: reported features of embryogenic cells. ${ }^{3,6,13,20}$ Such observations suggest that some cells in the explant have become embryogenic.

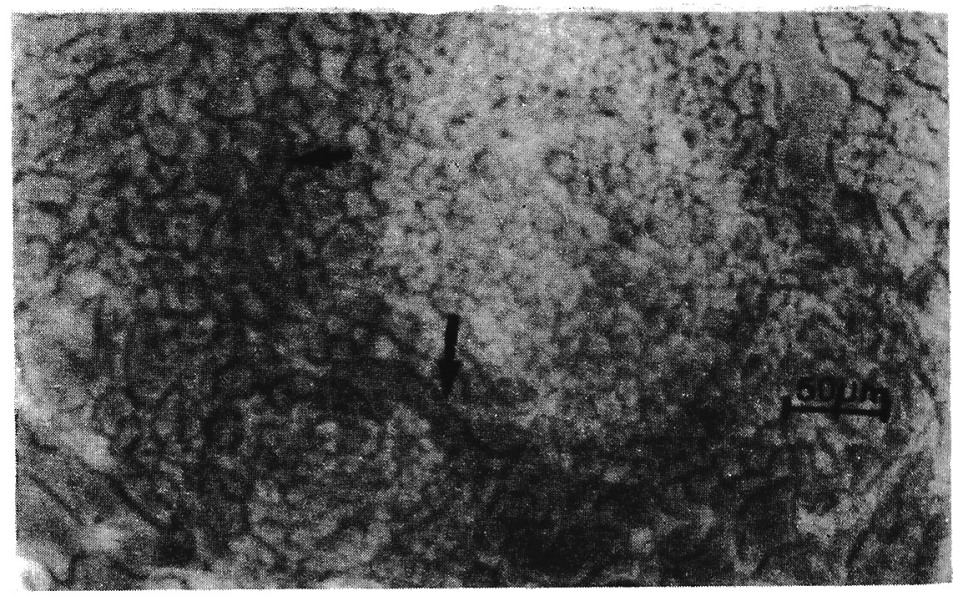

Figure 3: LS of explant 8 weeks in 2,4-D and BAP (groups of cells physically separated by a "thick wall" are illustrated) (the arrow shows one such group).

In Kolikuttu, whitish nodular tissues were seen on explant at 8-9 wks while in Embul, it was observed at 9-10 wks. Nodular structures were also observed along the veins of leaf primordia. Nodules were in clusters, smaller in size and were of various sizes and shapes. Formation of such nodular structures is reported in somatic embryogenesis of Crocus sativus, ${ }^{21}$ Oryza sativa ${ }^{22}$ and in Musa cv Bluggoe (ABB). ${ }^{3,23,24}$ It was also noted that at this time, the explants were completely disorganized and no trace of a shoot structure was observed. In both cultivars at week eleven, disorganized explants were filled with globules. At the end of week 12, globules started separating from the loosely arranged disintegrating parenchyma (Fig. 4) and globules of different sizes were released to the medium.

Thereafter globules of different sizes and shapes were seen in the medium. During this time, globules were continuously being released to the medium. The nodular tissues were formed only on the upper surface of the explant which did not show browning. No growth was observed at the lower, cut surface which became brown soon after inoculation. Also, callus formation was not observed probably due to higher amounts of phenolic compounds present in damaged parenchyma cells. 


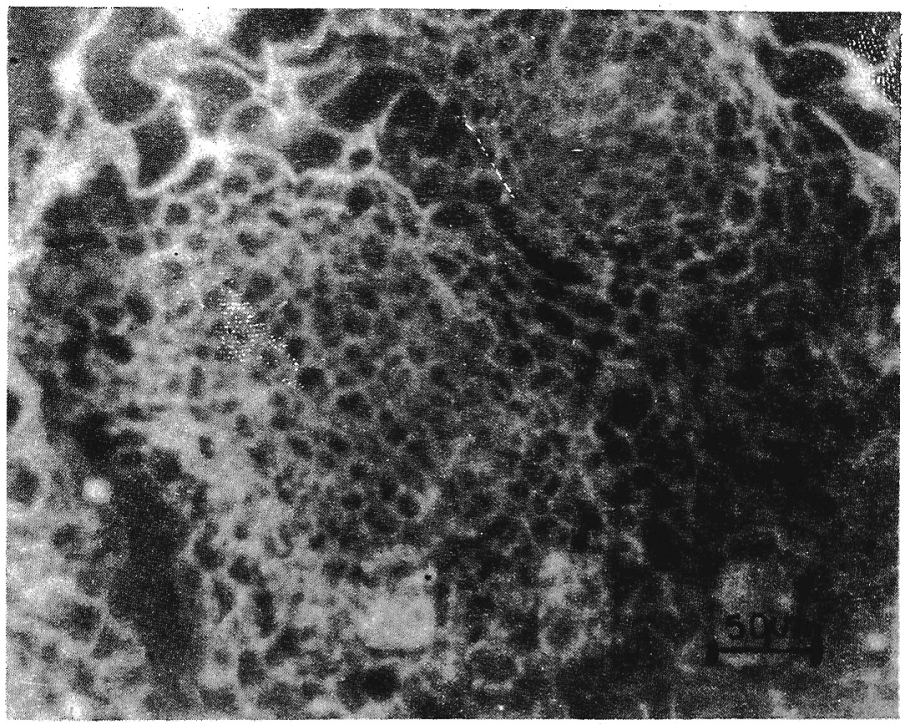

(a)

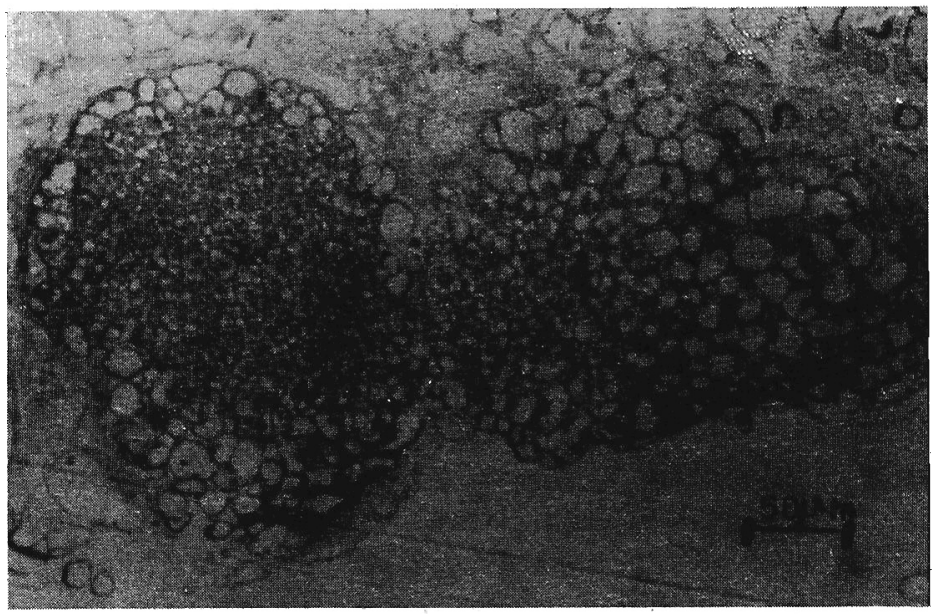

(b)

Figure 4: a) LS of explant at week 12, illustrating release of globules from the explant b) A similar stage in Musa cv Bluggoe (ABB) ${ }^{3}$

Globulár structures were white, compact and had loosely arranged cells at the surface. The size of the globules ranged from $1.0-3.5 \mathrm{~mm}$ diameter. The two types of globular structures previously reported in cv Bluggoe $(A B B)^{3}$ could be identified in the present study. As reported, the smaller globules (diameter $<2 \mathrm{~mm}$ ) contained mainly embryogenic cells while, larger globules had parenchyma cells at the centre. 
The globules of size $2 \mathrm{~mm}$ or less were developed into somatic embryos (bipolar structures) through transfer of proembryos initially to MS with ABA $(1.25 \mathrm{mg} / \mathrm{L})$ for two wks and then to media without growth regulators for another two wks (Fig. 5). The observations suggest that initiation of somatic embryos . from the uppermost part of in vitro shoots of Musa is possible in 2,4-D and BAP in liquid medium. In most plant species, for the induction of somatic embryos, the presence of 2,4-D alone or in combination with cytokinin, has been reported. . $3,6,22,25,26$ In the present study, 2,4-D together with BAP induced somatic embryogenesis. However as reported, distinct stages including early growth and embryo maturation in somatic embryogenesis required sequential changes in the medium composition especially the growth regulators. ${ }^{27}$

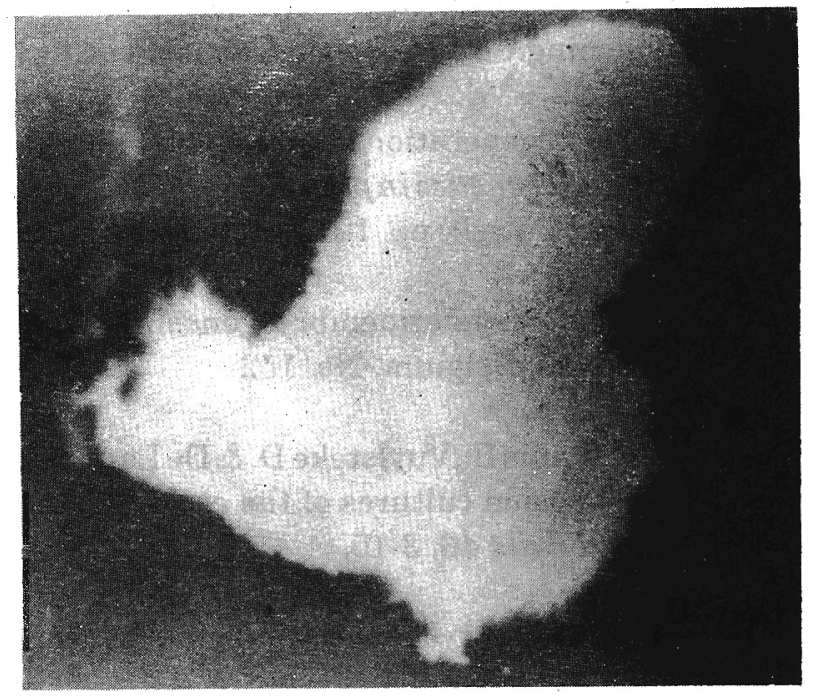

Figure 5: A somatic embryo in Musa cv Embul (AAB).

The embryogenic structures are developed without growing through a callus phase. Thus, there appears to have been a direct induction of embryogenic cells from meristematic cells. A similar pattern of somatic embryo development is reported in $\mathrm{cv}$ Bluggoe $(\mathrm{ABB}) .^{3}$ In some other studies, involvement of an intermediary callus stage is also reported in Musa but with different explants. . $^{83,24,28}$

The observations also suggest a variation in the time of somatic proembryo formation in cultivars of Musa. This is probably because, embryogenic determination in vitro is the result of many factors such as explant, growth regulators, culture conditions, osmosis etc. Any variation in these factors may affect embryogenic determination which may reflect on the time of embryo formation. It is reported that embryogenesis can be suppressed at any stage of embryo development due to unfavorable conditions. ${ }^{6,13}$ The study suggests that 
undifferentiated cells (meristematic) are a promising explant for direct induction of somatic embryos. Initiation of globules from undifferentiated cells suggest a higher genetic stability in them.

\section{Acknowledgement}

Financial assistance from the International Atomic Energy Agency (SRL/05/ 030 ) is gratefully acknowledged.

\section{References}

1. Sharp W.R., Clades L.S. \& Maraffa S.B. (1980). The physiology of in vitro asexual embryogenesis. In: Horticulture Review. Vol. 64. (Ed. J. Janik). pp. 268-310. AVI Publishing Co., Westport, Connecticut.

2. Vasil I. \& Vasil V. (1986). Regeneration in cereal and other grass species. In: Cell culture and somatic cell genetics in plants. Vol 3. Plant regeneration and genetic variability. (Ed. I.K. Vasil) pp. 121-150. Academic Press, New York.

3. Sannasgala K. (1989). In vitro somatic embryogenesis in Musa. Ph.D. thesis. Katholic University Leuven, Belgium. No. 152.

4. Dhed'a D., Dumortier F., Panis B.,Vuylsteke D. \& De Langhe E. (1991). Plant regeneration in cell suspension cultures of the cooking banana cv Bluggoe (Musa spp. ABB group). Fruits 46: 3-10.

5. Stefanik B. (1994). Somatic embryogenesis and plant regeneration of gladiolus. Plant Cell Reports 13: 386-389.

6. Williams E.G. \& Maheswaran G. (1986). Somatic embryogenesis: factors influencing co-ordinated behaviour of cells as an embryogenic group: a review article. Annals of Botany 57:443-462.

7. Hirimburegama K. (1996). In vitro somatic embryogenesis in angiosperms with special reference to monocotyledons. A review article. Vidyodaya Journal of Science. Vol. 6. (In press).

8. Cronauer S \& Krikorian A.D. (1983). Somatic embryos from cultured tissues of triploid plantains (Musa, ABB). Plant Cell Reports 2: 289-291.

9. Banerjee N., Schoof J., Hollevoet S., Dumortier F. \& De Langhe E. (1987). Aspects and prospects of somatic embryogenesis in Musa, ABB, cv. Bluggoe. Acta Horticulture 212: 727-729. 
10. Novak F.J., Afza R., Van Duren M., Perea-Dallos M., Conger B.V. \& Xiaolang T. (1989). Somatic embryogenesis and plant regeneration in suspension cultures of dessert (AA and AAA) and cooking (ABB) bananas (Musa spp). Biotechnology 7: 154-159.

11. Natesh S. \& Rau M.A. (1984). The Embryo. In: Embryology of angiosperms (Ed. B.M. Johri) pp. 377-434. Springer-Verlag, New York.

12. Escalant J.V. \& Teisson C. (1988). Embryogenese somatique cheq Musa spp. C R Academic Science (Paris), No 306, serie 111: 277-281.

13. Sannasgala K., Dumortier F.M. \& De Langhe E. (1990). Somatic embryogenesis from Musa proliferating shoot tips: histological details. In: In vitro mutation breeding of banana and plantain I. pp. 24-28. IAEA, Vienna

14. Liyanage H. (1992). Synchronization of somatic embryo development in Daucus carota. Ph.D. Thesis. University of Tokyo, Japan.

15. Liyanage H. (1995). A study of fractionated carrot (Daucus carota) somatic embryo cultures. Proc. Sri Lanka Ass. Advmt. Sci. 51(1): 78-79.

16. Gupta P.K., Timmis R., Carlson W.C., Grob J. \& Welty E. (1993). Somatic embryogenesis: a possible tool for large scale propagation of forestry species. In: Advances in developmental biology and biotechnology of higher plants. Proceedings, 1st Asia-Pacific conference on Plant cell and tissue culture, Taejon, Korea. September 1993.

17. Stover R.H. \& Simmonds N.W. (1987). Bananas. Tropical agriculture series. 3rd edition. Longman Scientific and Technical publishers.

18. Murashige T. \& Skoog F. (1962).A revised medium for rapid growth and bioassay with tobacco tissue cultures. Physiologia Plantarum 15: 473-497.

19. Berlyn G.P. \& Miksche J.P. (1976). Botanical microtechniques, and cytochemistry. Iowa State University Press. USA.

20. Kikuchi A., Satohs S \& Nakamure N. (1995). Differences in pectic polysaccharide between carrot embryogenic and non embryogenic callus. Plant Cell Reports 14: 279-284.

21. Koul A.A.S., Ram G. \& Koul B.L. (1994). Somatic embryogenesis and regeneration of plantlets in saffron Crocus sativus L. Indian Journal of Experimental Biology 32: 135-140. 
22. Raval M. \& Chatto B.B. (1994). Role of media constituents and proline in callus growth, somatic embryogenesis and regeneration of Oryza sativa cv. Indica. Indian Journal of Experimental Biology 31: 600-603.

23. Bakry F. \& Rossignol L. (1985). Analyse des capacites de callogenese et d'organogenese obtenuse a partir de differents tissues de bananiers (Musa spp. Musaceae). Fruits 40: 697-707.

24. Krikorian A.D. (1987). Callus and cell culture, somatic embryogenesis, androgenesis and related techniques for $M u s a$ improvement. In: Banana and plantain breeding strategies (Eds. G. Persley \& E. De Langhe) pp. 128135. (ACIAR Proceedings No. 01).

25. Patel D.B., Brave D. M., Nagar N. \& Metha A.R. (1994). Somatic embryogenesis in a local cv of Musa. Indian Journal of Experimental Biology 32: $740-744$.

26. Arun B., Tiwar K.N., Singh B.D.\& Dhari R. (1994). Indian Journal of Experimental Biology 32:835-837.

27. Ammirato P.V. (1986). Hormonal control of somatic embryo development from cultured cells of caraway: effects of abscisic acid, zeatin and gibberellic acid. Plant Physiology 59: 579-586.

28. Jarret R.L., Fisher J.B. \& Litz R.E. (1985). Organ formation in Musa tissue culture. Journal of Plant Physiology 121: 123-130. 